\title{
Evolução, onde estamos?
}

Muito tem sido debatido sobre a prática, na área da saúde, baseada em evidências científicas. A atuação racional baseada em fatos concretos, em detrimento da prática romântica baseada nas experiências pessoais. Evoluímos para uma fase de adequação dos novos dados de evidências científicas na prática ortodôntica. Talvez porque a Ortodontia, como especialidade, apresente um índice de sucesso razoavelmente alto, resultando na maioria das vezes em pacientes satisfeitos, a transição para condutas baseadas nas recentes evidências científicas seja mais lenta. Como um exemplo claro, podemos citar o tratamento em 1 ou 2 fases para a Classe II. A sustentação científica hoje demonstra claramente que o tratamento em apenas uma fase, no início da dentadura permanente - estágio pubertário - oferece resultados mais rápidos e eficientes. Entretanto, por pressões de mercadológicas, psicológicas ou familiares, ou por convicções pessoais dos profissionais, ainda muito se pratica a correção precoce desta má oclusão, culminando em tratamentos extensos e onerosos, ainda que também oferecendo um bom resultado final. Justamente pelo fato do resultado final ser positivo, se comparado àquele obtido em apenas uma fase (mais eficiente e barata), cada um segue o seu "romantismo". Isto também se aplica às preferências para tipos de expansores, opções de distalizadores e mecânicas deste ou daquele autor, extrações versus não extrações, etc. O fato é que a evolução e o amadurecimento da conduta baseada em evidências nos conduzirá à convergência, na medida em que passemos a ser menos românticos e mais racionais. Ou será que todo o dinheiro gasto em pesquisas para o embasamento científico será em vão?

No Tópico Especial desta edição, publicamos um histórico dos braquetes e suas prescrições. Com detalhes, o leitor poderá verificar a diversidade de idéias que a Ortodontia conta hoje para o "correto" posicionamento dentário, por meio do desenho dos acessórios ortodônticos. Mais do que um compêndio dos recentes avanços dos braquetes, este trabalho nos inspira a questionar e criar pesquisas que sustentem a aplicação de cada idéia que motivou os autores a criarem suas prescrições. Como diria nosso ilustre professor Alberto Consolaro (consultor desta revista e autor de diversos artigos e livros), "semear", "seminar", "seminários" ou debates sobre "onde estamos" no quesito bases científicas para o uso deste ou daquele dispositivo, sem dúvida, ocorrerão. O romantismo precisa ceder à racionalidade também neste campo.

Nesta edição, o artigo sobre a função do canino desempenhada pelo pré-molar também compreende outra semente de estudo, pois ainda é tida como controversa. Quantos dogmas ainda terão que ser vencidos?

Sobre mecânica ortodôntica e resultados, destacamos o estudo com método dos elementos finitos sobre o posicionamento da alça $\mathrm{T}$, o estudo com implantes metálicos sobre as modificações decorrentes do uso do bionator de Balters, bem como os efeitos distalizadores do aparelho Pendex.

Duas condutas clínicas extremamente úteis ao ortodontista recebem mais uma evidência científica para serem adotadas, o uso do bochecho antibiótico antes da sessão de atendimento e o jateamento das bandas ortodônticas. Com um desenho objetivo e claro, Weissheimer e colaboradores avaliaram o procedimento de jateamento com óxido de alumínio, empregando alguns materiais de uso rotineiro para cimentação de bandas, e concluíram a sua eficácia para todos os cimentos.

Também soma-se às evidências, e diria de forma alarmante, que um simples procedimento de profilaxia com pedra pomes e água põe em risco o profissional, o paciente e a auxiliar. $\mathrm{O}$ artigo de Gonçalves e colaboradores indica que a adoção de um bochecho com clorexidina $0,12 \%$, antecipadamente à sessão ortodôntica, minimiza significantemente o risco de contaminação de todos os envolvidos no atendimento clínico.

Destacamos ainda o excelente trabalho com microscopia eletrônica de varredura sobre a integridade da superfície dos braquetes de titânio e de aço após receberem fluoreto de sódio.

O comportamento eletromiográfico dos músculos masseter e temporal, após a correção da mordida cruzada posterior, é apresentado por Rodrigues e colaboradores. E a presente edição é contemplada com mais uma pesquisa sobre a DTM.

A seção $O$ que há de novo na Odontologia traz duas curiosidades abrangendo nossa profissão e a seção Entrevista apresenta o professor Carlos Eduardo Francischone. O professor nos antecipa alguns assuntos que serão abordados no $4^{\circ}$ Encontro Internacional Dental Press, que ocorrerá de 7 a 9 de setembro deste ano em Maringá. O professor Francischone é nacional e internacionalmente reconhecido pela sua excelência clínica em reabilitação bucal e estará dividindo o ciclo de cursos com os professores Kokich (Seattle-EUA), Jorge Faber (Brasília-DF), Capelozza Filho (Bauru-SP) e Marcos Janson (Bauru-SP).

Encerro este editorial reforçando a mensagem de que as evoluções da Ortodontia realmente sejam testadas e colocadas em prática, no seu sentido científico. Neste campo precisamos ser menos românticos e mais racionais!

\section{Boa leitura!}

Adilson Luiz Ramos 